\author{
I. O. Vakulenko, Dr. Sc. (Tech.), Prof., \\ orcid.org/0000-0002-7353-1916, \\ S. O. Plitchenko, \\ orcid.org/0000-0002-0613-2544, \\ N. H. Murashova, \\ orcid.org/0000-0003-2758-0749, \\ V. N. Bohomaz, Cand. Sc. (Phys.-Math.), \\ orcid.org/0000-0001-5913-2671
}

Dnipropetrovsk National University named after Academician V. Lazaryan, Dnipro, Ukraine, e-mail: plit4enko@ukr.net

\title{
CONCEPT OF DETERMINING THE FRICTION STIR WELDING MODE
}

Purpose. To determine the optimal mode of friction stir welding of aluminum alloy.

Methodology. $2.5 \mathrm{~mm}$ thick plates made of aluminum alloy $\mathrm{AMg} 5$ with chemical content of alloying elements within grade composition were used as a material for the research. Friction stir welding was carried out using specially designed equipment with a preselected form and dimensions of working tool. At different ratios of the working tool rotation frequency the forces of pressing and speed of its movement along the connecting edges determined the metal heating degree and the quality of welded joint formation. Temperature of the connecting edges heating was determined by thermocouples immersed in metal at different distances from the welded joint. Rotational speed of the working tool was from 800 to $1600 \mathrm{~min}^{-1}$ with the effort of pressing to the plate surface from 580 to $1370 \mathrm{~N}$ and the speed of movement along the joint of $50 \mathrm{~mm} / \mathrm{min}$.

Findings. On the basis of different ratios of the working tool rotation speed and pressing to the connecting edges, there were determined conditions for achieving the effect of constant softening during friction stir welding. In order to achieve a high level of welding joint quality during friction stir welding it is necessary to carry out the process at high revolutions of the working tool and low levels of pressing to the connecting edges.

Originality. At the constant speed of the working tool rotation proportional increase in alloy temperature from increasing the level of its pressing to the connecting edges is disturbed by achievement of conditions of the dynamic softening processes development.

Practical value. The concept of choosing the technological parameters of welding process is determined, when it is preferred to increase in speed of the working tool rotation when the level of its pressing to the connecting edges decreases.

Keywords: friction stir welding, rotations of the working tool, pressing force, heating temperature, aluminum alloy, deformation

Introduction. Friction stir welding (FSW) [1] refers to diffusion technologies. They are characterized by the lack of change in the aggregate state of the connected edges metal. Metal heating is achieved by converting mechanical energy into heat by the friction from interaction with the working tool surfaces.

Working tool determines the process of formation and distribution of thermal energy in the welding zone, its size and shape influence quality of the welded joint. In this case, the right choice of the main parameters of the instrument, namely the diameter and shape of the shoulder and the pin, is an important problem.

Each part of the tool provides certain functions when converting mechanical energy by friction into the heat. So, the shoulder provides approximately $80 \%$ of the total energy. The rest accounts for the pin, depending on the contact conditions. Therefore, the main role in the welding process is given to the shoulder and the choice of its diameter.

The sufficiently complex form of working tool is due to the need for specific distribution of the heating temperature along the area of contact surfaces. In some cases, it is necessary to make the work surfaces of the tool with thread, grooves, spirals [2], and others. This

(C) Vakulenko I. O., Plitchenko S. O., Murashova N.H., Bohomaz V.N., 2018 makes it possible to destroy the oxide film of the aluminum alloy surfaces at high level, as well as to increase the diffusion degree between the weld metal, which in turn improves mechanical properties of the welded joint.

The working tool pin is intended for distribution of thermal energy over the welded joint thickness, crushing oxide films of the ends of the welding surfaces and their activation, ensuring diffusion during welding.

The form of the working tool pin can vary considerably depending on its diameter, inclination angle of the tool during welding, thickness of the base metal and its chemical composition, and other features, which in turn will influence the welded joint quality. Sometimes the pin surface can be corrugated or threaded that makes it possible to control the flow of plasticized metal and direct it to the sealing of certain segments of the joint, which reduces the probability of occurrence of such defect as lack of root penetration.

As compared to the technologies of partial or full melting the use of friction stir welding can significantly reduce the metal overheating degree in the area of thermal influence. Perspective directions of such technology application involve connecting elements from dissimilar materials that form heterogeneous melts or chemically unstable multiphase mixtures during crystallization. The resulting connections using traditional technolo- 
gies, such as electric arc welding, will be of very low quality in comparison with derivative metal materials.

Analysis of the previous research. The results of experimental studies [3,4] determined sensitivity of the welding joint quality according to the friction stir technology not only to increase in the level of metal material plasticity, but also from achieving a certain degree of its stir in the area of welding joint. Based on this, one of the reasons for the need to maximize heating of the edges is to increase the homogeneity of the metal when stirring and increase the metal density due to decrease in the number of cavities in the joint area [5, 6]. Thus, formation of welded joints to a large extent should be determined by the peculiarities of development of the diffusion mass transfer processes, and increase in the metal heating degree is a well-founded decision [7]. Analysis of numerous studies of the internal structure of metal materials after welding joint formation according to the technology of friction stir welding indicates a qualitative coincidence in the indicators with the structural state of the metal after hot reduction.

According to results of studies of the internal structure elements of metal materials, obtaining qualitative welded joints is possible due to the achievement of temperatures in the joint area not lower than the level of $0.8-0.9$ from the melting temperature $(\mathrm{K})$. On the other hand, different sensitivity of metal materials to overheating should limit the metal heating temperature. Indeed, heterogeneity of the plastic deformation distribution in the joint area, along with the proportional acceleration of the diffusion mass transfer processes, will lead to a significant anisotropy of the microstructure and corresponding decrease in the complex of properties. Thus, a substantiated limitation of the edge heating degree can be used to inhibition of structural transformation processes that contribute to the formation of its significant heterogeneity [8].

Objectives of the article. The article is aimed to determine the concept of choosing the mode of friction stir welding of aluminum alloy.

Material and methodology of the research. The FSW process (Fig. 1) consisted of the following operations. The working tool 1 , which was given a certain rotational speed, approached the base metal 3 and 4 until a dense contact at a small angle $\left(2 \ldots 3^{\circ}\right)$ was established. Moreover, constant normal effort of the tool was given, according to which the shoulder 5 was immersed in the blank to a depth of about $10 \%$ of the total thickness of the welding edges.

In this case, due to the formation of frictional forces on the contact surfaces of the shoulder 5 , the pin 6 and the connecting elements 3 and 4 the heating of the base metal begins. Using the pin, the heat is almost evenly distributed across the thickness of the edges. After reaching the required heating degree the metal starts to be stirred.

The welding tool was made using high-speed steel R9, which retains its mechanical properties at elevated temperatures of the tool heating during the friction stir welding of most aluminum alloys. Also, the tool was subjected to a special heat treatment.

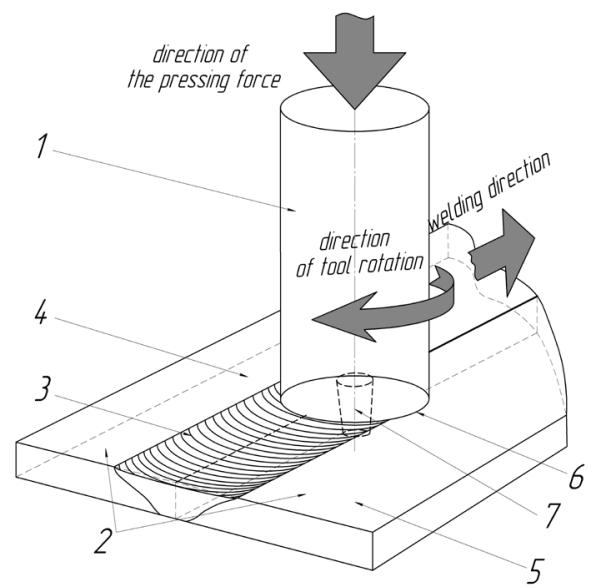

Fig. 1. The process of welding two blanks from AMg alloy 5:

1 - welding tool; 2 - welded metal; 3 - welding seam; 4 advancing side tool; 5 - retreating side tool; 6 - shoulder; $7-\operatorname{pin}$

The form and dimensions of the working tool used in the work are presented in Fig. 2. The length of the pin was found using the ratio of $0.9 \ldots 0.95 \%$ of the thickness of the base metal.

Diameter of the working tool pin was chosen to take into account the conditions for maintaining the strength of the pin itself when entering the cold metal at the beginning of the welding process and during subsequent welding, reliable stirring of joint contact surfaces metal, even in case of a slight gap or deviation of the tool movement trajectory from the joint axis.

Friction stir welding was carried out using specially developed equipment, which, along with the selected parameters of the working tool met the requirements [9] and made it possible to obtain a quality welded joint.

$2.5 \mathrm{~mm}$ thick plates made of aluminum alloy AMg5 with chemical content of alloying elements within grade composition were used as a material for research. At different ratios of the working tool rotation frequency the forces of pressing and speed of its movement along the

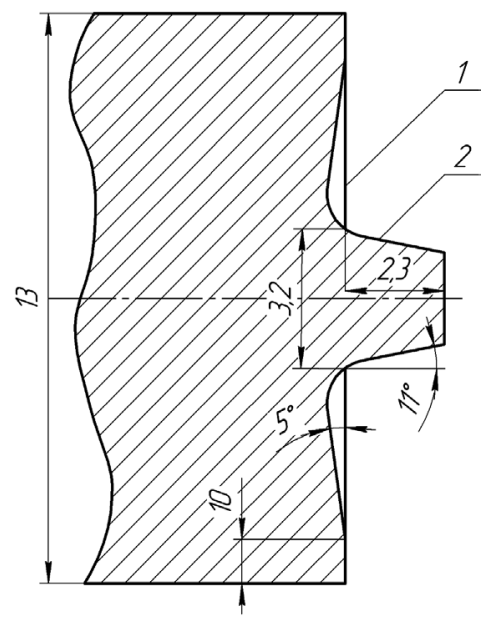

Fig. 2. Schematic diagram of working tool for friction stir welding:

1 - shoulder; 2 - pin 
connecting edges determined the metal heating degree and the quality of welded joint.

The heating temperature of the connecting edges was determined by thermocouples of the chromel-aluminum system immersed in metal at different distances from the welded joint axis at the intersection of welded joint.

Rotational speed of the working tool was the value from 800 to $1600 \mathrm{~min}^{-1}$ with the pressing effort to the plate surface from 580 to $1.4 \mathrm{kN}$ and the speed of movement along the seam of $50 \mathrm{~mm} / \mathrm{min}$.

Explanation of scientific results. According to the external signs of the diagram (Fig. 3), the heating temperature increase of the connecting edges $(T)$ during friction stir welding from the pressing force $(P)$ and rotation speed of the working tool $(v)$ can be divided into three sections, with a qualitatively different nature of the ratio of technological parameters.

The first section $(O A)$ is directly proportional increase in the heating temperature of the connecting edges from the pressing force. The second section $(A B)$ is $T$ increase under conditions of the constant force of the tool pressing. A characteristic feature of the third section $(B C)$ is the outpacing decrease in the force $P$ at the increase in the metal heating temperature.

At the section $O A$ for the studied rotational speeds of the working tool the monotonous increase in degree of its pressing to the connecting edges corresponds to the directly proportional increase in the temperature of metal heating. Approximating the experimental data by direct dependencies, one can determine the existence of quite expected influence from the tool rotation speed on the edge heating (Fig. 4). At the same level of pressing, increasing the tool rotation speed leads to increase in the speed of heating the metal.

On this basis, the tool rotation speed should, to a greater extent, determine both the level of critical value of the tool pressing, and the transition nature to the second part of the dependence, which is confirmed by the data $[3,5,7]$. As the analysis of diagrams shows, with an increase in $v$ the characteristic features of the transition

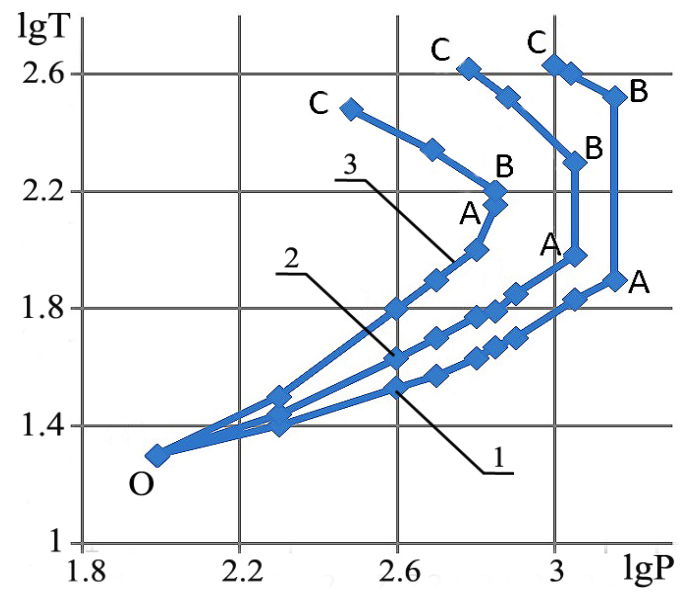

Fig. 3. Influence of pressing force and rotation speed of the working tool on the heating temperature of connecting edges:

$1--800 \mathrm{~min}^{-1} ; 2-1250 \mathrm{~min}^{-1} ; 3-1600 \mathrm{~min}^{-1}$

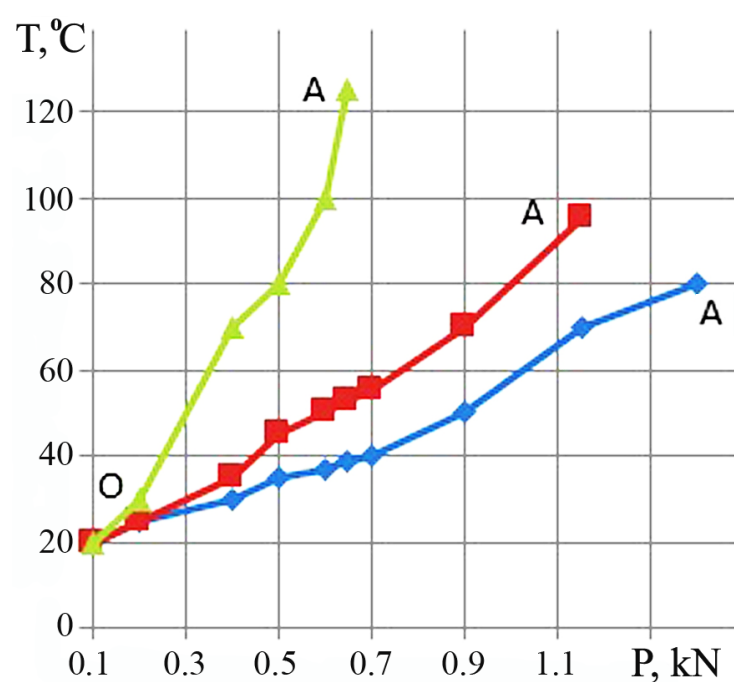

Fig. 4. Influence of pressing force and rotation speed $\left(\bullet-800\right.$; - 1250; $\Delta-1600$ min $\left.^{-1}\right)$ of the working tool on the heating temperature of the connecting edges at the section $O A$

moment to the second section $A B$ is a decrease in the level of critical force of pressing and a more flat form of the dependence itself.

On the other hand, the moment of deviation from a directly proportional ratio can be taken as the beginning of qualitative change development in the internal structure of the alloy. Indeed, on the basis of numerical experimental studies it was determined that in the process of plastic deformation increase in the heating temperature of metal material is accompanied by acceleration of the diffusion mass transfer processes. This in turn should influence the ratio of the development of strengthening and softening processes [10].

For the alloy under study and the interval of the working tool rotation speeds the moment of deviation from the direct proportional ratio corresponds to approximately the same temperature at the level of $90{ }^{\circ} \mathrm{C}$. Under conditions of unchanged $v$, proportional increase in the heating temperature with the pressing force increase can be achieved only by exaggeration of the strengthening effect over the softening one. Initial stages of deviation from the proportional dependence indicate that there were achieved conditions when the rate of structural transformations (displacement and annihilation of the crystalline structure defects during deformation) can no longer be compensated by the additional introduction of the crystalline structure defects. On this basis, the first stage should be recombination of dislocations, which leads to the formation of dislocation polygonal groups in the form of the emergence of different types of boundaries with small angles of disorientation.

Conditions of accelerated increase in the heating temperature at almost unchanged $P$ force correspond to completion of the transition zone from the $O A$ to $A B$ section. According to the presented nature, behavior of the alloy under study is, to a large extent, similar to the development of superplastic flow in metallic materials. To this end, it is necessary to evaluate the probability 
and determine the nature of development of the internal reorganization processes in the alloy under investigation during the friction stir welding.

In the process of plastic deformation at elevated temperatures substructural transformations during development of dynamic polygonization processes correspond to the first qualitative signs of internal reorganization of metal material. When heating the most cold-deformed metal materials, the temperature of the beginning of the polygonal boundaries formation $\left(T_{P}\right)$ is subject to the ratio

$$
T_{P}=0.4 T_{M},
$$

where $T_{M}$ is the melting temperature $\mathrm{K}$ ). According to the given dependence for the investigated alloy during the processes of plastic deformation the temperature of the beginning of substructural transformations development should be at the level of $100{ }^{\circ} \mathrm{C}$. In comparison with static conditions (cold plastic deformation and subsequent metal heating) deformation at elevated temperatures leads to acceleration of processes of substructural transformations. This is caused by the fact that during separate heating of cold-deformed metal internal stresses from the introduced crystalline structure defects are the main driving force for movement and redistribution of dislocations. And polygonization development occurs only under the influence of linear tension of dislocations.

As for the deformation at elevated temperatures together with acceleration of diffusion mass transfer leads to the emergence of additional factor - continuous action of stress, which greatly facilitates the development of substructural transformation processes. Thus, one should expect a shift of the moment of the beginning of the substructural transformation development during friction stir welding towards lower temperatures, as compared to the estimation according to the ratio for $T_{P}$.

Using analysis of dependencies $\lg T=f(\lg P)$ (Fig. 3) the moment of violation of the direct proportional increase in the edge heating temperature from the force of the working tool pressing can be considered as the evidence of appearance of qualitative changes in the internal structure of alloy. In comparison with the practically identical temperature of the beginning of deviation from the directly proportional ratio $\left(90{ }^{\circ} \mathrm{C}\right)$, the moment of achieving a constant level of pressing (point $A$, Fig. 4) has a definite dependence on the working tool rotation speed and makes a value in the range of $100 \ldots 120{ }^{\circ} \mathrm{C}$. Detailed study determined that with increase in the value $v$ the temperature of achievement of the constant pressing force (point $A$, Fig. 4) shifts towards higher loads.

Taking into account the known experimental data on the study of substructural transformations in the process of hot reduction of metal materials, it is likely that the presented nature of the alloy behavior corresponds to the initial stages of the development of dynamic polygonization processes. Formation of polygonal subboundaries of different perfection degrees with simultaneous increase in the accumulated number of crystalline structure defects occurs at the background of steady in- crease in the heating temperature of connecting edges. Thus, the maintenance of conditions of constant pressing force with the increase in the heating temperature can be provided only by the corresponding accumulation of the crystalline structure defects during the hot reduction of metal.

At the same time, increase in the efficiency of metal heating with increase in the working tool rotation speed has a definite practical significance when developing the concept of friction stir welding. To this end, an estimation of the angular coefficient $(K)$ for the dependencies (Fig. 4) according to the relation was carried out

$$
K=\frac{\Delta T}{\Delta P}
$$

Having analyzed the given dependence, we can be conclude that increase in the value $K$ forms a value from 0.05 to $0.16 \mathrm{deg} / \mathrm{N}$ for the corresponding speeds of rotation $v\left(800 \ldots 600 \mathrm{~min}^{-1}\right)$. Thus, it can be assumed that when developing the welding technology under conditions of the same power of the process, it should be preferred to increase the tool rotation speed and to reduce the degree of its pressing to the connecting edges.

Existence of the sections with a constant level of tool pressing deserves a detailed assessment. For the tool rotational speed of $800 \mathrm{~min}^{-1}$, the temperature interval of the existence of a constant force $P(1.4 \mathrm{kN}$, Fig. 4) is $250{ }^{\circ} \mathrm{C}$ (from 100 to $350{ }^{\circ} \mathrm{C}$ ). Increasing $v$ from 1250 to $1600 \mathrm{~min}^{-1}$, the section length along the temperature scale decreases and equals 120 and $30{ }^{\circ} \mathrm{C}$ respectively, and the maximum value of $P$ decreases from about 1 to $0.65 \mathrm{kN}$ (Fig. 4).

In the first approximation, existence of the sections of the edge heating temperature increase at a constant level of pressing, according to external signs corresponds to the conditions of the steady nature of hot reduction. Execution of the given ratio between $T$ and $P$ is possible only by maintaining the balance between the development of strengthening and softening processes, which is ensured by the immutability of the dislocation density at deformation. Excessive number of introduced dislocations to support the conditions for continuous propagation of the plastic flow should be compensated by the development of annihilation processes during recombination of dislocation groups. Indeed, if one estimates the value of plastic deformation as the proportional to the tool pressing force, a greater number of dislocations per one rotation in metal at a speed of $800 \mathrm{~min}^{-1}$ should be introduced as compared to the speed of $1600 \mathrm{~min}^{-1}$.

Taking into account the high level of energy of the stacking faults in aluminum-based alloys, accelerating the development of substructural transformations, for example, under conditions of $v=1600 \mathrm{~min}^{-1}$, will take place at relatively low plastic deformations caused by pressing of $0.65 \mathrm{kN}$. With increase in the degree of deformation from the action of force of $1.4 \mathrm{kN}$, the increased number of introduced dislocations in metal will lead to increase in their concentration and violation of the conditions for their exit from the slipbands. As a result, the complications arising during development of 
dynamic polygonization processes will lead to a shift of the moment of the third section beginning to the dependencies towards higher temperatures (Fig. 3).

Analysis of the results of aluminum alloy behavior during friction stir welding indicates existence of a certain sensitivity of the development of substructural transformations processes to technological parameters of the process.

For the section $B C$ (Fig. 3), the characteristic feature is impossibility to prevent decrease in the tool pressing force with increase in the heating temperature of the connecting edges (Fig. 5).

Analysis of numerical experimental data indicates that the given behavior in general terms corresponds to the conditions for the development of dynamic metal softening. For most aluminum-based alloys, the ratio between the degree of softening and proportion of the recrystallized volume makes it possible to determine the nature of the processes of structural transformations.

Thus, with a decrease in the absolute value of the angular coefficient $K$ approximately by $5 \ldots 6$ times the specified limit can be taken as an indicator separating the area of influence completion from the development of dynamic polygonization processes and beginning of recrystallization acceleration.

According to the presented dependence, softening effect to the level of $50 \%$ should be ensured by the development of dynamic substructural transformation processes. In this case, the proportion of the recrystallized alloy does not exceed $10 \%$. Further increase in the softening degree during hot reduction is, to a greater extent, ensured by the development of the dynamic recrystallization processes.

Evaluating the level of alloy softening at the third section (Fig. 5) using the pressing force reduction in the process of friction stir welding $(\Delta P)$, the characteristic inverse proportional dependence $\Delta P$ on the working tool rotation speed confirms the above mentioned provisions.

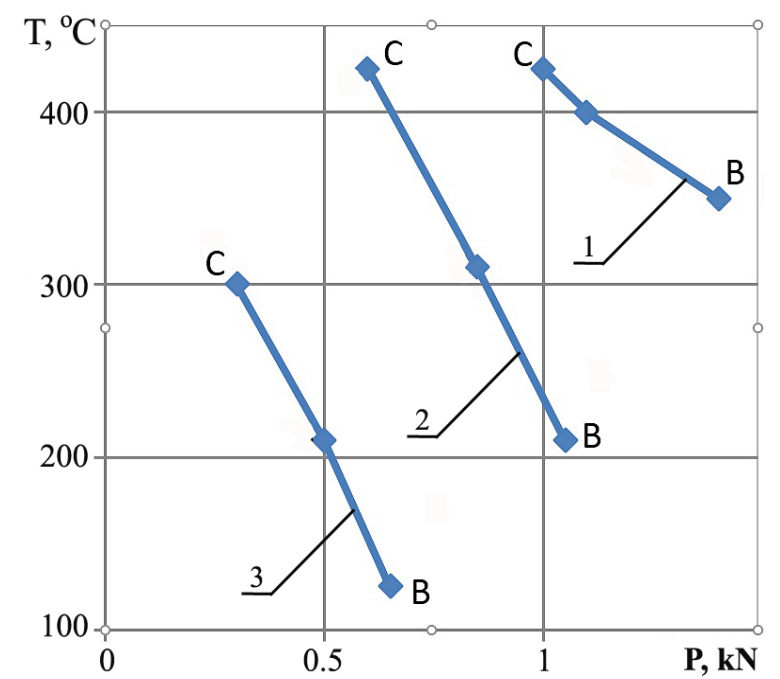

Fig. 5. The ratio between $P$ and $T$ for the $B C$ section depending on $\mathrm{v}$ :

$1--800 \mathrm{~min}^{-1} ; 2-1250 \mathrm{~min}^{-1} ; 3-1600 \mathrm{~min}^{-1}$

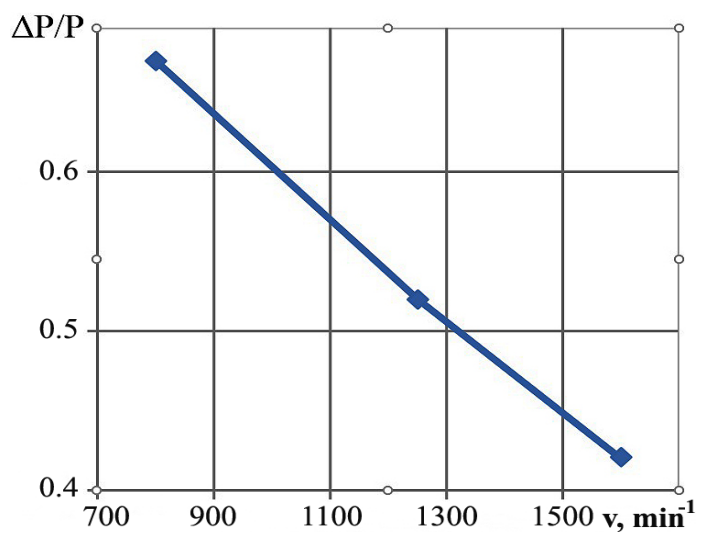

Fig. 6. Influence of $v$ on the degree of metal softening at the section $B C$

When decreasing $v$ from 1600 to $800 \mathrm{~min}^{-1} \Delta P$ increases from 40 to about $70 \%$ (Fig. 6).

Thus, it can be assumed that the alloy softening effect at high speeds of the tool rotation is, to a greater extent, caused by the development of the dynamic substructural transformation processes. When reducing rotation speed and increasing the pressing force, the softening effect begins to be more determined by increase in the influence of dynamic recrystallization process development.

Conclusions.

1. At constant speed of the working tool rotation, the proportional increase in the alloy temperature from increasing the level of its pressing to the connecting edges is disturbed by the achievement of conditions of the dynamic softening processes development.

2. On the basis of different ratios of the working tool rotation speed and pressing to the connecting edges, the conditions for achieving the effect of constant softening during friction stir welding are determined.

3. The concept of choosing the technological parameters of the welding process is determined, when it is preferred to increase the working tool rotation speed decreasing the level of its pressing to the connecting edges.

\section{References.}

1. Thomas, W. M., Nicholas, E. D., Needham, J.C., Murch, M. G., Peter Temple-Smith, P. and Dawes, C.J. Welding Institute Cambridge, 1995. Friction welding. The United Kingdom. Pat. 5,460,317 [online]. Available at: <https://patents.google.com/patent/US5460317A/ en $>$ [Accessed 3 May 2017].

2. Burford, D. A., Wichita State University, 2008. Friction stir welding tool. U.S. Pat. 2008/0011810 A1 [online]. Available at: <https://patents.google.com/patent/ US20080011810A1/en?oq=US+2008\%2f0011810> [Accessed 9 May 2017].

3. Villegas, J.F., Dominguez, J.V., Ochoa, G.V. and Unfried-Silgado, J., 2017. Thermo-Mechanical Modeling of Friction-Stir Welding Tool Used in Aluminum Alloys Joints. Contemporary Engineering Sciences, 10(34), pp. 1659-1667. DOI: 10.12988/ces.2017.711156. 4. Poklyatsky, A. G., 2008. In fluence of the parameters of the friction welding process with mixing on the formation of 
joints of aluminum alloys with a thickness of $1.8 . .2 .5 \mathrm{~mm}$. [pdf], pp. 27-30. Available at: <http://patonpublishinghouse.com/as/pdf/2008/as200810all.pdf $>$ [Accessed 10 March 2017].

5. Bevilacqua, M., Ciarapica, F. E., D’Orazio, A., Forcellese, A. and Simoncini, M., 2017. Sustainability analysis of friction stir welding of AA5754 sheets. In: $10^{\text {th }}$ CIRP Conference on Intelligent Computation in Manufacturing Engineering - CIRP ICME '16 [online], pp. 529-534. Available at: <https://ac.els-cdn.com/S2212827116306990/ 1-s2.0-S2212827116306990-main.pdf?_tid=db5edae2c482-11e7-98bc-00000aab0f02\&acdnat $=1510145376 \_03 a$ 49f9adb53342f8d8b9530dfc08aa2> [Accessed 15 October 2017].

6. Poklyatsky, A.G., Klochkov, I.N. and Motrunich, S. I., 2015. Some advantages of butt joints of thinsheeted deformable aluminum alloys AMg5M and AMg6M, obtained by friction stir welding, in comparison with TIG, Avtomaticheskaya svarka, 7, pp. 18-23. Available at: <http://patonpublishinghouse.com/as/ pdf/2015/pdfarticles/07/4.pdf $>$ [Accessed 10 March 2017].

7. Ravi Sankar, B. and Umamaheswarrao, P., 2017. Modelling and Optimisation of Friction Stir Welding on AA6061 Alloy. Materials today: Proceedings, 4(8), pp. 7448-7456. DOI: 10.1016/j.matpr.2017.07.076.

8. Vakulenko, I. O., Plitchenko, S.O. and Nadezhdin, Yu. L. Dnipropetrovsk National University of Railway Transport named after V. Lazaryan, 2012. The method for welding friction with the mixing of alloys based on aluminum. Ukraine. Pat.75698.

9. Vakulenko, I.A. and Plitchenko, S.A., 2017. Determination activation energy of friction stir welding. In: Welding and Related Technologies: Proceedings $9^{\text {th }}$ International Conference of young scientists (23.0527.05.2017). National academy of sciences of Ukraine, Institute of Electric Welding named after E. O.Paton [pdf], pp. 54-58. Available at: <http://wrtys.com. ua/2017/wpcotent/uploads/Paton_Proceedings_2017_ Small_New.pdf $>$ [Accessed 22 October 2017].

10. Dalder, E., Pastrnak, J.W., Engel, J., Forrest, R. S., Kokko, E., Mcternan, K. and Waldron, D., 2008. Friction stir welding of thick-walled aluminum pressure vessels [pdf], pp. 40-44. Available at: <https://app.aws.org/ www/wj/2008/04/WJ_2008_04.pdf> [Accessed 22 September 2017].

\section{Концепція визначення режиму зварювання тертям 3 перемішуванням}

\section{І.О. Вакуленко, С. О. Плітченко, Н. Г. Мурашова, В. М. Богомаз}

Дніпропетровський національний університет залізничного транспорту імені академіка В. Лазаряна, м. Дніпро, Україна, e-mail: plit4enko@ukr.net

Мета. Визначення оптимального режиму зварювання тертям з перемішуванням алюмінієвого сплаву.

Методика. Матеріалом для досліджень були пластини товщиною 2,5 мм з деформівного алюмі- нієвого сплаву АМг5 із хімічним вмістом легуючих елементів у межах марочного складу. Зварювання тертям з перемішуванням проводили на спеціально розробленому устаткуванні, із попередньо обраними формою й розмірами робочого інструменту. За різних співвідношень частоти обертання робочого інструменту, сили притискання й швидкості переміщення його вздовж з'єднувальних кромок визначали ступінь розігріву металу та якість формування зварного з'єднання. Температуру розігріву з'єднувальних кромок визначали зануреними в метал термопарами на різній відстані від зварного шву. Швидкість обертання робочого інструменту складала від 800 до $1600 \mathrm{xB}^{-1}$ при зусиллі притискання до поверхні пластин від 580 до 1370 Н і швидкості переміщення уздовж шву 50 мм/хв.

Результати. На основі різних співвідношень швидкості обертання робочого інструменту та притискання до з'єднувальних кромок визначені умови досягнення ефекту постійного пом'якшення при зварюванні тертям з перемішуванням. 3 метою досягнення високого рівня якості зварного шва при зварюванні тертям 3 перемішуванням треба здійснювати процес за підвищених обертів робочого інструменту й низьких рівнів притискування до 3'єднувальних кромок.

Наукова новизна. При постійній швидкості обертання робочого інструменту, пропорційне підвищення температури сплаву від збільшення рівня його притискання до з'єднувальних кромок порушується досягненням умов розвитку процесів динамічного пом'якшення.

Практична значимість. Визначена концепція вибору технологічних параметрів процесу зварювання, перевага віддана збільшенню швидкості обертання робочого інструменту при зниженні рівня його притискання до з'єднувальних кромок.

Ключові слова: зварювання тертям з перемішуванням, оберти робочого інструменту, сила притискання, температура нагріву, сплав алюмінію, деформація

\section{Концепция определения режима сварки трением с перемешиванием}

\section{И.А. Вакуленко, С.А. Плитченко, Н. Г. Мурашова, В. Н. Богомаз}

Днепропетровский национальный университет железнодорожного транспорта имени академика В.Лазаряна, г. Днепр, Украина, e-mail: plit4enko@ukr.net

Цель. Определение оптимального режима сварки трением с перемешиванием алюминиевого сплава.

Методика. Материалом для исследований были пластины толщиной 2,5 мм с деформируемого алюминиевого сплава АМг5 с химическим содержанием легирующих элементов в пределах марочного состава. Сварку трением с перемешиванием проводили на специально разработанном оборудовании, с предварительно выбранными формой и размера- 
ми рабочего инструмента. При различных соотношениях частоты вращения рабочего инструмента, силы прижимания и скорости перемещения его вдоль соединительных кромок определяли степень разогрева металла и качество формирования сварного соединения. Температуру разогрева соединительных кромок определяли погруженными в металл термопарами на разном расстоянии от сварного шва. Скорость вращения рабочего инструмента составляла от 800 до 1600 мин $^{-1}$ при усилии прижима к поверхности пластин от 580 до 1370 Н и скорости перемещения вдоль шва 50 мм/мин.

Результаты. На основании различных соотношений скорости вращения рабочего инструмента и силы прижимания к соединительным кромкам определены условия достижения эффекта постоянного размягчения при сварке трением с перемешиванием. С целью достижения высокого уровня качества сварного шва при сварке трением с перемешиванием необходимо осуществлять процесс при повышенных оборотах рабочего инструмента и низких уровнях прижима к соединительным кромкам.

Научная новизна. При постоянной скорости вращения рабочего инструмента, пропорциональное повышение температуры сплава от увеличения уровня его прижатия к соединительным кромкам нарушается достижением условий развития процессов динамического размягчения.

Практическая значимость. Определена концепция выбора технологических параметров процесса сварки, предпочтение отдано увеличению скорости вращения рабочего инструмента при снижении уровня его прижатия к соединительным кромкам.

Ключевые слова: сварка трением с перемешиванием, обороты рабочего инструмента, сила прижатия, температура нагрева, сплав алюминия, деформация

Рекомендовано до публікації докт. техн. наук В.О.Заблудовським. Дата надходження рукопису 03.07.17. 